\title{
Research on Undergraduate Innovative Talents Cultivation in Higher Agricultural Colleges and Universities
}

\author{
Chunfang Wang \\ School of Humanities, Jilin Agricultural University, Changchun 130118, China
}

(E-mail:854325524@qq.com)

Key words: Agricultural Colleges and universities; innovation; talent cultivation

\begin{abstract}
China's innovative talent training of agricultural colleges and universities started late, which has not yet formed a perfect training model, and teaching practice faces many difficulties. This paper, combined with foreign experience on cultivation of innovative talents, explores the evolution process of talents in higher agricultural universities in China, analyzes and sums up the difficulties that the agricultural universities in China are facing in the teaching process, and puts forward some feasible suggestions.
\end{abstract}

\section{Introduction}

China is a large agricultural country, where farmers occupy the vast majority of the total population of the country. With the development of economic society, the hidden social injustice in the two partition system of urban and rural areas is becoming more and more obvious. China's rural construction is still in a state of backwardness, low productivity, economic backwardness, cultural backwardness, serious surplus of labor and a series of problems seriously hinder the development of rural areas. Under the current education system in our country, the rural population is commonly in the spillover phenomenon, the comprehensive quality of the farmers is not high, and the key to construct a new socialist countryside is to cultivate innovative agricultural talents. Higher agricultural colleges and universities undertake the mission of transporting high level talents for the country's rural economic development, and the higher agricultural education has a very important influence on the construction of the new socialist countryside.

\section{Subject of the Cultivation of Innovative Talents in Foreign Countries}

Higher agricultural education in foreign countries has not clearly put forward the innovative talents training mode, while the concept of innovative talents education has been run through the whole education system. The cultivation of innovative talents in foreign countries is explored from the aspects of educational philosophy, teaching methods and curriculum arrangement, which is summarized as follows:

2.1 Pay Attention to Students' Independent Innovation and Advocate the Cultivation of Comprehensive and All-round Talents

Worldwide countries, in the reform of higher education, place the cultivation of innovative ability and innovative spirit in an important position. From the beginning of last century, the United States set up innovation center in some universities to guide students' creative invention activities [1]. Many universities in Europe have also opened a series of courses to specially train and develop students' creative ability and methods, such as research methodology, creative skills, intelligence and creativity training and so on. The former Soviet Union has established more than 100 Institutes of Invention in the country, organized college students to learn basic principles and methods for engaged in the invention creation, and carried out technological innovation experiments [2]. At the same time, many countries also put forward to cultivate comprehensive and all-round talents. They think there will not be a great cultural breakthrough if there is no combination. In the reform of higher education that the former Soviet Union carried out in 1970s, it put forward to cultivate talents with a scientific world outlook, comprehensive knowledge, multiple and specialized skills, 
and broad knowledge. The United States and many European countries have put forward the goal of training creative talents and interdisciplinary talents. German educator Jaspers put forward that the university should train the concept of "all-around developed person", and pursue innovation in the premise of "all-around developed person".

\subsection{Promote Heuristic and Inductive Teaching Mode and Respect Students' Individuality and Interest}

Some universities in Europe and the United States are very advocating personality development and creative training, so the school promote heuristic and inductive mode in its own teaching methods. Japan's "Education Basic Law" once explicitly pointed out that, the starting points of Japanese education are required to achieve the aim of education and to respect the students. From the situation of the reality, cultivate students' enterprising spirit, and require to mutually respect and cooperate.

\subsection{Curriculum Setting "Advance with the Times" and Curriculum Content Closely Combined with Social needs}

From the historical development of American universities, American colleges and universities have been constantly updating their concept of talent training according to the requirements of the society and self-perfection. The curriculum reform is always the focus of the reform of American college education, and the change of curriculum content has become the "vane" of American college education reform.

\section{Explore the Historical Evolution and Basic Experience of Talent Training in Higher Agricultural Colleges and Universities}

When the New China was founded in 1949, the national independently set higher agricultural colleges and universities are only 18, the agriculture colleges (departments) set in the Comprehensive University are 30, a total of 48 colleges (departments). These colleges (departments) are mostly distributed in the coastal areas, few in the mainland, the border area is even scanty. From 1952 to 1953, in accordance with the relevant provisions of the "Common Program" and the "Interim Regulations of Higher Education", Ministry of Education has adjusted higher education institutions. The number of agricultural colleges and universities is increased to 29, and the important position of agricultural colleges has been affirmed [3]. During this period, the talent training of higher agricultural colleges and universities follow the mode of the former Soviet Union. Taking the "professionals" of "new intellectuals" as the goal, in the professional setting, implement a highly-unified teaching plan and syllabus. This kind of talent training mode imitated the former Soviet Union has led the idea of running higher agricultural colleges and universities in a long period of time.

Since the outbreak of the "Cultural Revolution" movement in 1966, colleges and universities implemented the training goal of both socialist-minded and professionally competent, promoted the combination of education and productive labor, and "part-time" learning mode. This school running mode, to a certain degree, caused decline in the quality of education and disorder of teaching activities, many schools are completely stopped during the enrollment, and the school-running idea and talent-training concept have also been affected even destroyed.

After the third Plenary Session of the 11th CPC Central Committee, higher agricultural education has gradually been restored, the agricultural colleges and universities personnel training work becomes more standardized, and the enrollment is also more flexible. During the period from 1987 to 1993, the Undergraduate Catalog was revised for two times. Higher agricultural school carried out large-scale reform of teaching adjustment and talents training mode, began to get rid of the shackles of the former Soviet Union education thought and mode. the highly uniform situation of higher agricultural education in socialist planned economic system is broken. At the same time, the credit system, the elective system, the scholarship system, the pre-elimination system and a series of teaching management system reforms were implemented in teaching management system. As a result, the majority of students can study with direction according to the needs of society, personal basis and desire, and employment market trends. In a word, since the publication of 
Decision of the Central Committee of the Communist Party of China on the Reform of Educational System in 1985, the running of higher agricultural colleges and universities has become more and more open, and talents training mode has become diversified [4].

In 1995, in the National Science and Technology Conference, after Comrade Jiang Zemin put forward the well-known thesis "Innovation is the soul of a nation's progress, is the inexhaustible power for the prosperity of a country", the agricultural colleges began to re-examine the training mode of talents, and began to try quality education.

Since the foundation of New China, with the deepening of reform and social stability, the college layout structure tends to be reasonable, scale and benefit have great development, educational reform is gradually deepening, educational system and management system reform is healthily developed, the school autonomy is expanding, and school-running conditions are gradually improved [5]. Specifically speaking, the basic experience of personnel training in higher agricultural institutions can be summarized as the following four points:

1) Adhere educational goals of serving the "three rural". For higher agricultural education serve the "three rural", it is necessary to take the initiative to adapt to the rural economy and rural social development needs, through the cultivation of new rural to construct the needed innovative talents.

2) Follow the objective law of the growth and cultivation of talents. In the personnel training target and talent training program, it is required to teach students in accordance with their aptitude, promote the comprehensive development of talent, improve the comprehensive quality of people, correctly handle the relation between social adaptation and transcendence of good talent training objectives, and enhance the awareness and ability of agricultural high-level talents for serving "the farmers".

3) Adhere to the school-running concept that "Teaching, research, and production are combined". Teaching is the basic functions of universities, and scientific research can promote teaching and enhance talent research ability and innovation ability; the production can also promote the teaching, and through the practice, the practical ability of talents to solve specific problems will be improved.

4) Insist on strengthening the construction of teaching conditions. The excellent learning environment, advanced experimental equipment, modern information technology, complete experiment and practice base, and scientific management methods and system are the important foundation to cultivate the high-quality talents, which is an important guarantee for the development of higher agricultural education.

\section{Difficulties in Cultivating Innovative Talents in Higher Agricultural Colleges}

Training innovative talents is a systematic project, which involves in the teaching management, discipline construction, personnel training and so on. China's agricultural colleges and universities cultivation of innovative talents started late and failed to form a comparatively perfect innovative talent training model. The teaching practice faced with some difficulties, mainly reflected in the following aspects.

\subsection{Fuzzy Innovative Education Positioning and Insufficient Systematic and Complete Theoretical System}

The understanding of innovative talents in agricultural colleges is not unified, and it still stays in the surface sense of the goal of talent training. To carry out the practice in the cultivation of innovative talents in colleges and universities, it needs more to consider the training mode of innovative talents from teaching needs and teaching reform, while not effectively place this measurement on the problem of "three rural" and the needs of construction of new countryside [6]. Even some schools simply understand the higher agricultural education as the inheritance of agricultural knowledge, and do not pay attention to the training of students' innovative consciousness and ability. 


\subsection{Not Close Combination of Curriculum with Agricultural Practice and Lack of Innovation}

The curriculum setting of higher agricultural colleges and universities is not reasonable, and the combination with the actual agricultural production is not close, lack of innovation. In the curriculum setting, agricultural colleges common practice is to separate the general courses and specialized courses, course study and field practice according to learning time. And the curriculum content is old that many textbooks still take the content of last century as the model, lack of introduction of new agricultural knowledge. Some courses focus on research and light skills, ignore the introduction to basic agricultural production, seriously disjointed with the current agricultural production reality. In this course setting, students' sense of innovation is not strong, lack of innovative spirit, and innovative ability is not strong.

\subsection{Old Teaching Mode and Lack of Interest and Research Value}

In the current agricultural colleges teaching process, the methods to cultivate students' inquiry ability and innovation spirit are still not widely used, including "heuristic teaching method", "case teaching method", and "situational teaching method" [7]. The traditional instilling teaching method still occupies the leading position. This kind of teaching method is single, obsolete and backward. Due to entirely taking the teacher as the leading of classroom teaching and the teaching content as the core, it ignores the cultivation of students' questions awareness, and it does not leave enough thinking time and thinking space for students, making the students' learning potential inhibited, not conducive to the cultivation of students' innovative spirit.

\section{Methods and Countermeasures to Promote the Cultivation of Innovative Talents in Agricultural Colleges and Universities}

Based on the main problem of the innovative talents discussed above, combined with the training goal positioning in the "three rural" condition, for the current agricultural colleges to correctly set the cultivation of innovative talents, to break the traditional concept of education, and to set up the training concept of new agricultural personnel training mechanism, the focus is to build scientific agricultural talents training mechanism, and at the same time to improve school conditions, providing a powerful guarantee on the school system and educational resources for the cultivation of creative talents.

\subsection{Scientifically Set Innovative Personnel Training Objectives}

At present, colleges and universities should cultivate high-level and high-quality agricultural talents who have the contribution spirit and innovative consciousness of serving the new socialist countryside construction, and make some creative contributions to the construction of "three rural". From the economic perspective, they represent the advanced agricultural productivity, undertake the mission of revitalizing agricultural economy, promoting the development of rural economy, and leading farmers creation [8]; from the cultural perspective, they should become the core power for creating good and new rural civilization and morality and improving the quality of farmers; from the aspect of the system, they are important promoters and participants for the formation of the new rural democratic management mechanism.

\subsection{Change the Traditional Education Idea and Set up the Education Teaching Idea of Innovation-supreme}

In the process of traditional education management, students obey is taken as the management validity index, which often ignores the student's reasonable request, and suppresses the student's innovation consciousness. Teachers are accustomed to take the students understanding and grasping as the teaching goal, teaching process are set in advance in the program, and students "unconventional" problems and the way of thinking are gradually corrected to conform to the predetermined conclusion requirements [9]. The traditional education idea has already contained the student's creative thinking to a great extent, not conducive to the cultivation of creative talents. Therefore, for colleges to cultivate innovative talents, it is necessary to break the traditional education mode as soon as possible and set up the innovation-oriented teaching idea. 


\subsection{Establish the Training Objective of Cultivating Agricultural Compound Innovative Talents}

For a long time, the cultivation of "agricultural professionals" and "agricultural experts" is the innovative talents target of agricultural university. With the development of agriculture, agriculture has been greatly extended, "agricultural professionals" and "agricultural experts" training policy is not conducive to the mutual adaptability of modern agriculture, but also not beneficial for the all-round development of people [10]. As modern agriculture has been involved in many industries and fields, the innovative talents it required are supposed to be compound talents.

\subsection{Give Full Play to the Characteristics of Agricultural Colleges and Universities}

The characteristic of university reflects the value-orientation of the presidents and staffs in the process of school-running, and once it is formed, it will have a subtle influence on school subjects and students' behavior, which is like an invisible hand, dominating the internal various resources allocation. Scientifically, rationally and effectively plan the development of school discipline, and implement the characteristics in practice, which will have a guiding role in the training of innovative talents.

\section{Conclusion}

In recent years, in order to meet the needs of cultivating innovative talents for the construction of new socialist countryside, the agricultural colleges and universities are actively exploring and researching, but the effect is not obvious and the cultivation of innovative talents is still the weak link of the teaching reform of agricultural colleges and universities. The cultivation of innovative talents is a systematic work, which runs through the whole teaching process. Only by adhering to the education philosophy of cultivation of innovative talents, clarifying the cultivation target of innovative talents, and taking the development status of China's rural areas as the starting point, can the cultivation of innovative talents be organically integrated to the daily teaching work. In addition, it also needs our continuous exploration and improvement since that the innovative talent cultivation has a long way to go.

\section{References}

[1] Ren, J., Liu, L., Liu, H., Yan, M., \& Zhang, Q. (2013, June). Comparison of Innovative Talent Cultivation Pattern in America and China. In 2013 Conference on Education Technology and Management Science (ICETMS 2013). Atlantis Press.

[2] Bing, Z., \& Ji, S. (2015, August). A research on theory and practice of the innovative talent training mode in mechanical specialties: Illustrated by the example of the School of mechatronics Engineering, Harbin Institute of Technology. In Fluid Power and Mechatronics (FPM), 2015 International Conference on (pp. 1408-1411). IEEE.

[3] Chang, T. Y., \& Huang, K. L. (2013, July). Service-Learning Model of Cultural and Creative Talent Cultivation for the Bamboo Industry Cluster. In International Conference on Human-Computer Interaction (pp. 479-483). Springer Berlin Heidelberg.

[4] LIU, Z., HUANG, Q. Y., LIU, F., FENG, Y. P., TAN, W. F., \& DAI, K. (2013). Adherence to Teaching through Research and Cultivation of Innovative Talents: Exploration and Practice-Taking Resources and Environment Specialty of Huazhong Agricultural University for Example [J]. Journal of Huazhong Agricultural University (Social Sciences Edition), 4, 024.

[5] Chunhuan, R., \& Yunsheng, L. (2014). The Discussion of Animal Reproduction Science Experiment Teaching Reform and Innovative Talent Cultivation [J]. The Science Education Article Collects, 7, 034.

[6] Wang, F. Y., Mu, R. T., Liu, L. X., Sun, G., Ji, G. Q., \& Yang, C. H. (2016). The Innovative Research on Engineering Master Cultivation Mode Based on University-Enterprise Cooperation. In Proceedings of the 6th International Asia Conference on Industrial Engineering and Management Innovation (pp. 1013-1018). Atlantis Press.

[7] Sun, D. L., She, J., Lv, P., Lee, J., Ma, A. L., Pai, M. F., ... \& Zhang, X. D. (2014). Study on the 
Mode for Cultivation of Diversified Informationized Innovative and Entrepreneurial Talents Based on Five Systems. In Applied Mechanics and Materials (Vol. 519, pp. 1638-1641). Trans Tech Publications.

[8] Xi, G. U. A. N. (2013). The Analysis on Training Way of Innovative Talent in Agricultural Economic and Management Specialties_-Taking Innovation of Fujian Agriculture and Forestry University as an Example. Journal of Wuyi University, 1, 025.

[9] Wang, H., \& Chen, Y. (2013, October). The Cultivation of Regional Innovative Culture is an Important Link to Enhance the Regional Soft Power. In International Academic Workshop on Social Science (IAW-SC-13). Atlantis Press.

[10] Hu, Q., Hao, P., Cui, W., \& Zhu, W. (2013, June). Innovative Talent Training Model to Actively Explore the Hierarchical Culture. In 2013 the International Conference on Education Technology and Information System (ICETIS 2013). Atlantis Press. 